Piotr Kręzel (Łódź)

(iD) https://orcid.org/0000-0001-6427-0286

\title{
The Political Ambitions of Serbian Patriarch ArseniJe IV Jovanović Šakabenta*
}

$\mathrm{T}$ he Turkish invasions of the Balkan Peninsula in the $14^{\text {th }}$ and $15^{\text {th }}$ centuries not only resulted in the loss of the sovereignty of the medieval Serbian state, but also majorly contributed to the erosion of the State-Church diarchy, which characterized the rule of the Nemanjić, the Lazarević and the Branković ${ }^{\text {. During }}$ the period of the Ottoman domination, the responsibility for the Serbian nation rested squarely on the shoulders of the Orthodox Church, and of the patriarch in particular'. That the leader of the Serbian Orthodox Church held sway over the Serbs also stemmed from the notion of the millet (lit. 'people', 'clan', 'nation'), which assumed that the spiritual leaders of non-Muslim communities living in the Ottoman Empire were their official representatives in the High Porte ${ }^{3}$, while

* This article has been written under the research project financed by the National Science Centre (Poland). Decision number: DEC-2014/12/T/HS3/00 555 (The Serbian ethnos. The period of patriarch Arsenije IV Jovanović Šakabenta (1726-1748)).

${ }^{1}$ For more information, see D. GIL, Serbscy etnarchowie jako kodyfikatorzy tradycji kulturowej, [in:] U spomen na Borivoja Marinkovića. Zbornik Filozofskog Fakulteta, ed. N. Grdinić, S. Tomin, N. VARNICA, Novi Sad 2014, p. 132-133.

${ }^{2}$ The importance of the leader of the Serbian Orthodox Church increased after the restoration of the Peć Patriarchate in 1557. See M. Mirković, Pravni položaj i karakter srpske crkve pod turskom vlašću (1459-1766), Beograd 1965, p. 91-106. For the context of the restoration of the Patriarchate, see M. МıкоєајсZак, Mehmed pasza Sokollu - problem przynależności etnicznej, państwowej i kulturowej, BP.AS 16, 2009, p. 59-69.

${ }^{3}$ For the Ottoman notion of the millet, see S. SHaw, The Ottoman View of the Balkans, [in:] The Balkans in Transition. Essays on the Development of Balkan Life and Politics since the Eighteenth Century, ed. B. Jelavich, C. Jelavich, London 1963, p. 61-62; IDEM, Historia Imperium Osmańskiego i Republiki Tureckiej (1280-1808), vol. I, trans. B. Świetlik, Warszawa 2012, p. 242-243; B. KAPLAN, Divided by Faith. Religious Conflict and the Practice of Toleration in Early Modern Europe, Cambridge-London 2007, p. 240-241. According to Slovenian anthropologist and ethnologist Božidar Jezernik, it is precisely because of the millet that the clergy was vested with numerous administrative and judiciary powers. All cases, including marriages, divorces, or succession proceedings were heard before a Bishop's court, so Christians did not have to turn to the Ottoman jurisdiction in civil cases. For more details, see B. JeZERnik, Dzika Europa. Bałkany w oczach zachodnich podróżników, trans. 
the lawfulness of their election was certified with a berat, a special document issued by a sultan ${ }^{4}$. Under such circumstances - created by the authorities in Istanbul - Serbian patriarchs not only attended to spiritual and theological matters, but also had to pay close attention to political, economic, and tax-related issues.

It was not uncommon that the actions of the Peć Patriarchate leaders were dominated by the secular dimension. This was caused, on the one hand, by the geopolitical situation in which they operated, and, on the other, by their personal political ambitions. One such Serbian leader was Arsenije Jovanović (1698-1748), who was selected patriarch in $1726^{5}$. From the very beginning of his service, he attempted, at his own discretion, to reorganize the Church structures which he controlled and to resolve the economic crisis of the Peć Patriarchate ${ }^{6}$. The aim of the present paper is to characterize the ideas and political ambitions which Arsenije IV Jovanović Šakabenta strove to realize in the late 1730s.

The situation which the patriarch and the whole Serbian nation found themselves in changed in 1737, when preparations commenced for another war between the Habsburg Monarchy and the Ottoman Empire ${ }^{7}$. The leader of the Serbian

P. Oczкo, Kraków 2007, p. 187-190. A more detailed description of the situation of non-Muslim (not just Serbian) population in the Ottoman state in the early modern period is offered by Daniel GoffMAN in The Ottoman Empire and Early Modern Europe, Cambridge 2004, p. 170-188. In Slavonic studies, the notion of the millet is equated with ethnarchy. The patriarch (the milletbaşı in the eyes of Istanbul) is considered to be the ethnarch (etnarh naciona). For more, see D. GIL, Prawosławie. Historia. Naród. Miejsce kultury duchowej w serbskiej tradycji i współczesności, Kraków 2005, p. 77; EADEM, Serbscy etnarchowie..., p. 132-139; I. Lis-Wielgosz, O trwałości znaczeń. Siedemnastowieczna literatura serbska $w$ stużbie tradycji, Poznań 2013, p. 34-35; EAdEM, Władza i rodowód. O wizerunku władcy w staroserbskiej literaturze, PSS 5, 2013, p. 177-178; EADEM, Władza turecka i strategie jej opisu w piśmiennictwie staroserbskim (na przykładzie krótkich form literackich - zapisów), BP.AS 21, 2014, p. 40-41.

${ }^{4}$ Berat is a sultan's certificate appended with an official seal, called tughra. For more, see H. INALciK, D. Quataert, Dzieje gospodarcze i społeczne Imperium Osmańskiego, Kraków 2008, p. 870.

${ }^{5}$ R. GrujIć, Pećki patrijarsi i karlovački mitropoliti u 18. veku, Sremske Karlovci 1931, p. 30-33.

${ }^{6}$ The difficult financial situation of the Peć patriarchate was a result of the repercussions of the Turkish authorities after Arsenije III Cronojević sided with the Austrians in 1689. For more information, see R. Grujić, Velika Seoba patrijarha Arsenija III Crnojevića iz južne Srbije u Vojevodinu pre dvestapedeset godina, Skoplje 1940, p. 326; H. Andonovsкi, Makedonija i Vojvodina. O nikim međusobnim vezama u prošlosti, ZMSDN 23, 1959, p. 6; V. STOJANČEvić, Presek kroz istoriju srpskih seoba od XIV do početka XVIII veka, ZMSI 41, 1990, p. 21; S. ČAKIĆ, Velika Seoba Srba i Patrijarh Arsenije III Crnojević, Novi Sad 1994, p. 108-225; T. Judah, The Serbs. History, Myth and the Destruction of Yugoslavia, London 1997, p. 46; N. MALcolm, Kosovo. A Short History, London 1998, p. 161.

${ }^{7}$ The Habsburg monarchy went to war with Turkey under the treaty on military alliance with Russia, which was signed on 9 January 1737 in Vienna. For more information on Austria's diplomatic efforts and military operations between 1737 and 1739, see K. RoIDER, The Reluctant Ally. Austria's Policy in the Austro-Turkish War, 1737-1739, Baton Rouge 1972, passim; IDEM, Futile Peacemaking: Austria and the Congress of Niemirov, AHY 12/13, 1976/1977, p. 95-116. The Russian Empire declared war on the Ottoman Empire on 23 April 1736. For the Russians, the casus belli was the passage of the Tatar troops (who were the sultan's vassals) through Dagestan, which at that time was under 
Orthodox Church had to side with one of the belligerents, since the theater of war was going to span the Peć Patriarchate, which was under his rule. The intelligence he received suggested that the Austrians were more likely to triumph. The situation on the Balkan front was dynamic, with ups and down for either side. However, in the second half of 1737, due to the ineptitude of the military commanders of Charles VI (1685-1740), and despite a considerable support from the SouthSlavonic (mostly Serbian) people, the Austrian troops lost the majority of their military gains (including Niš and Pirot) and had to retreat behind the DanubeSava line. As a result, Arsenije IV Jovanović Šakabenta decided to leave Peć for the Austrian-controlled territories because he was well aware that staying in Peć would have had tragic consequences both for him and the Serbs who sympathized with the Habsburgs. Emigrating to the Habsburg Monarchy together with Arsenije IV were leaders of the Serbian Orthodox Church, military commanders, and some of the Serbian clans from Kosovo and Metohija.

In November 1737, having arrived in the Habsburg state, Arsenije IV began negotiations with the Austrian military authorities concerning the conditions of the continued Serbian involvement in the war against the Porte ${ }^{8}$. He wanted to win as many rights and liberties as he could for the entire Serbian nation, which was under his jurisdiction. During the negotiations, he invoked the privileges granted to the Serbs by Charles VI's predecessors, i.e. Leopold I (1640-1705) and Joseph I (1678-1711) ${ }^{9}$. The talks were held in Vienna, and it is probably during his stay there that the patriarch drew up his nine-point political program ${ }^{10}$.

Russian occupation. The reference works on the causes, course, and ramifications of the RussianTurkish war of 1736-1739 include: А. Кочувинский, Граб Андрей Иванович Остерман и раздел Туриии. Из истории восточного вопроса. Война пяти тет (1735-1739), Одесса 1899, passim; А. БАЙов, Русская армия в иарствование императрицы Анны Иоанновны. Война России с Турицей в 1736-1739 г2., vol. I, Первые три года войны, Санкт-Петербург 1906, passim; С. Соловьев, История России с древнейшых времен (1725-1740), Москва 1963; Е. Шульман, О позиции России в конфликте с Туриией в 1735-1736 г2., БИС 3, 1973, p. 5-61; E. Anisimov, Rossija biez Pëtra, Sankt-Peterburg 1994, p. 405-423; W. MoRAwsKi, S. SzawŁowsKa, Wojny rosyjsko-tureckie od XVII do XX wieku, Warszawa 2006, p. 51-64; А. Широкорад, Турция. Пять веков противостояния, Москва 2009, р. 65-78.

${ }^{8}$ Arsenije IV was in Vienna between 16 December 1737 and 7 June 1738. S. GavrILović, Srpski nacionalni program patrijarha Arsenija IV Jovanovića Šakabente iz 1736-37. godine., ZMSI 44, 1991, p. 39-40.

${ }^{9}$ Cf. R. GrujIĆ, Kako se postupalo sa srpskim molbama na dvoru ćesara avstrijskog poslednje godine života patrijarha Arsenija III Čarnojevića, Novi Sad 1906, p. 3-41; S. Simeonović-Čokić, Srpske privilegije, [in:] Vojvodina II. Od Velike Seobe (1690) do Temišvarskog Sabora (1790), Novi Sad 1940, p. $48-85$.

${ }^{10}$ It needs to be mentioned that the document was not originally dated. For that reason, there is a number of hypotheses concerning the date of its creation. According to historian Slavko Gavrilović, who published the document and gave it a title, Arsenije IV's demands, summarized in a few points, were issued already before the Austrian-Turkish war and presented to representatives of the Habsburgs by archimandrite Vasilije in Belgrade at the beginning of 1737. However, this theory is 
In historiography (especially in South Slavonic historiography), this document is known as the "Memorandum of Arsenije IV Jovanović Šakabenta".

One of the most important points of the "Memorandum" provided that the territories claimed during the Austrian-Turkish conflict shall enjoy some sort of autonomy within the Habsburg monarchy. Therefore, a guarantee was sought that freedom of religion would be respected and that the administration of the Serbian Orthodox Church would have full independence. Consequently, Arsenije IV demanded that emperor Charles VI confirm the privileges granted to the Rascians by Leopold I between 1690 and $1695^{11}$. In accordance with these documents, the patriarch was to be given complete spiritual jurisdiction in Serbia, Albania, Bulgaria, Bosnia, Herzegovina, and other provinces (art. 1) ${ }^{12}$.

Another article concerned the Serbian territories claimed by the Austrians during the war. Arsenije IV did not want them to be considered as newly-acquired (It. Neoaqvistiche), as was the case of Slavonia, Srem, Banat, and Militärkommandatur des Königreichs Serbien: these territories were governed by the Hofkammer, Hofkriegsrat (Imperial War Council), or the Hungarian administration. In his document, the patriarch petitioned that the Serbian territories be governed

inconsistent with the account of Isaije Antonović, the eparch of Arad: in his letter to Vićentije Popović, the metropolitan of Karlovci, dated 2 February 1737, he wrote that Vasilije had merely presented, orally, a few imploring points, which were then taken down by Austrian scribes and translated into Latin. Antonovićs account of Vasilije's meeting with the emperor's representatives seems more plausible than Gavrilović's hypothesis because it is highly unlikely that the patriarch's emissary should have carried on him an openly anti-Turkish document as he was travelling through the Ottoman Empire. Had the Turks intercepted the "Memorandum", it would have had serious implications not just for Arsenije IV but also for the entire Serbian nation.

Historiography also offers no definitive answers as to the identity of the scribe who may have wrote the text in Italian. Given its syntax and vocabulary, the author was certainly not a native speaker. In Arsenije IV's inner circle, only protosyncellus Partenije Pavlović spoke Italian, which he probably learned during his time in the Montenegrin monastery of Savina, which at that time was under a strong influence of Italian culture. It is also certain that Partenije Pavlović was in Vienna with Arsenije IV, which supports the hypothesis that the "Memorandum" was written at the end of 1737 or at the beginning of 1738. Cf. Arhiv Srpske Akadamije Nauka i Umetnosti u Sremskim Karlovcima (cetera: ASANUK), Metropoliljsko-Patrijaršijski fond B (cetera: MPB), sig. 1737/64; Arhiv Srpske Akadamije Nauka i Umetnosti u Beogradu (cetera: ASANUB), sig. 7070; Avtobiografija Partenija Pavlovića episkopa posvećenja, SSio 15, 1905, p. 14-15, 17-19, 396-399, 430-432, 493-495, 526-528, 553-556; J. LANGER, Nord-Albaniens und der Herzegowina Unterwerfungs-Anerbieten an Oesterreich 1737-1739, Wien 1880, p. 239-304; S. GaVRILović, Srpski nacionalni..., p. 39-48; Znamenita dokumenta za istoriju srpskog naroda 1538-1918, ed. V. GaVrilović, D. Mikavica, G. Vasin, Novi Sad 2007, p. 53-56.

${ }^{11}$ For more information on the privileges which Leopold I gave to the Serbs living in the Habsburg monarchy, see Srpske privilegije od 1690 do 1792, ed. M. Kostić, J. Radonić, Beograd 1950, p. 19-45; D. DAvidov, Srpske privilegije carskog doma habzburškog, Novi Sad 1994, p. 89-102; P. KRĘZEL, Analiza językoznawcza przywilejów Leopolda I $z 1690$ r., WS. Sammelbände 46, 2012, p. 143-147.

${ }^{12}$ S. GAVRILOvić, Srpski nacionalni..., p. 42-43. The translation of the quotes was made by the author of the article. 
by a separate body, namely the Supreme Royal Tribunal (It. Supremo Tribunale Regio). Its seat was supposed to be the Serbian capital ${ }^{13}$, and it was to be composed exclusively of the Rascians (It. composto di membri Nazionali). Additionally, the Tribunal was to be superior to the newly formed local magistrates and dikasteria (It. loro Magistrati, e Dicasteg Nazionali, dipendenti dal' subd[elegat]o Tribunale). Arsenije IV also believed that the Tribunal should be independent and enjoy all powers necessary to rule on civil-law and criminal-law matters. Also, Vienna was supposed to be the seat of a separate Serbian chamber, such as those that Hungary, the Czech lands, and Transylvania have (art. 3) ${ }^{14}$.

The "Memorandum" did not explicitly state which territories would come under the jurisdiction of the new institutions. It is not clear if the patriarch only had in mind those territories which would be controlled by the Habsburg state after the war with Turkey had concluded, or maybe also those which were part of the Habsburg Monarchy prior to 1737 (such as the Military Command of the Kingdom of Serbia). Arsenije IV likely assumed that the vague demands presented to Charles IV could be made more specific at a later time, depending on the situation on the Balkan front.

The "Memorandum" offered a rather broad definition of the autonomy of the Serbian territories, especially with regard to taxation and military issues. Arsenije demanded from the emperor that taxes be collected at a very specific juncture so they would not be too much of a burden to the Serbian people. Additionally, he wanted tax collection to be performed by experienced administrative officers of the Illyrian-Serbian nation (art. 7) ${ }^{15}$, and the assets thus collected to be handed to those who shall be appointed with the emperor's decree to do so in a specific place (art. 7) ${ }^{16}$.

In his demands presented to Charles VI, Arsenije IV also raised some military issues. He proposed the creation of a few regiments made up of members of this nation, which will serve the Emperor (art. 9) ${ }^{17}$. These units were supposed to only answer to Serbian officers, while foreign nationals (mostly Germans) could only join them when invited by the Serbs. During peacetime, the soldiers of these regiments shall enjoy the same privileges and rights as the other units of the imperial militia do (art. 9) ${ }^{18}$, and during war, they shall receive wages and food provisions from the empire's resources. The "Memorandum" allowed for the encampment of the German garrison on the Rascian fatherland, but at the same time it was stated that it shall not interfere in any civilian matters of this nation (art. 6) ${ }^{19}$.

\footnotetext{
${ }^{13}$ It was not specified which city should fulfill this function.

${ }^{14}$ S. GaVRILOVIĆ, Srpski nacionalni..., p. 43.

${ }^{15}$ Ibidem, p. 43-44.

${ }^{16}$ L. cit.

${ }^{17}$ Ibidem, p. 44.

${ }^{18}$ L. cit.

${ }^{19}$ Ibidem, p. 43.
} 
The patriarch also believed that the Habsburg monarchy should recognize the Serbian nobility, who would enjoy

all the liberties and privileges enjoyed by such nobles as palatines (those who are in possession of villages, manors, and properties), barons, and others (art. 8$)^{20}$.

A closer look at this point of the "Memorandum" reveals that Arsenije IV had a limited grasp of the Habsburg monarchy's political reality. This is especially visible in his definition of the term "palatine" ${ }^{21}$, which for him denoted a member of the nobility, but in reality referred to a state official. Under the act of 1458 (Articuli pronuntiati de officio palatinatus) ${ }^{22}$, the Hungarian palatine (palatinus regni Hungariae) was invested with a number of significant powers. In particular, he could govern the country during an interregnum, act as a mediator between the ruler and the Hungarian nobility (counties) during any disputes, and exercise the judicial power, as well as fill in for the ruler during his absence in a given territory (locum tenes) ${ }^{23}$. It is believed that it is precisely because of this very wide range of prerogatives that emperor Charles VI, between 1732 and his death, never designated anybody for this office. The tradition of appointing the palatine of the Crown of Saint Stephen was only revived by Mary Theresa in 1741. This rather long period of vacancy was taken advantage of by $k n e z^{24}$ Atanasije Rašković (1697-1753), who usurped the authority of the palatine at the beginning of 1738 , though he only appointed himself the palatine of the Serbs (palatinus von Rassien in den Alten Wallachey). Arsenije IV approved of this state of the affairs and until the end of the 1730s used this term in reference to the Serbian $k n e z^{25}$. It has to be noted that some of the documents issued by the Imperial War Council in Vienna during the Austrian-Turkish war also referred to Rašković as palatine ${ }^{26}$. Rašković himself gave up the claim to the title when the Austrian military authorities agreed to promote him to the rank of colonel ${ }^{27}$.

${ }^{20}$ Ibidem, p. 44. Art. 8 of the "Memorandum" is rather vague. It is not clear whom Arsenije IV regarded as the Serbian nobility. He may have meant the familial knezes, but this issue is underspecified.

${ }^{21}$ Some Serbian historians believe that Arsenije IV raised the issue of the "palatine" on purpose because he wanted to gauge the emperor's stance on the idea of appointing the "Serbian palatine". For more information, see S. GaVRILOvić, Srem od kraja XVII. do sredine XVIII. veka, Novi Sad 1979, p. 270.

${ }^{22}$ The articles were in force in the territories of the Crown of Saint Stephen until 1848.

${ }^{23}$ I. Barinyay, Palatini regni Hungariae, Tyrnaviae 1753, p. 203-208. M. Horváth, Statistica regni Hungariae et partiam eidem adnexarum, Posonii 1802, p. 249.

${ }^{24} \mathrm{Knez}$ was the administrative-territorial leader of a community (often a few villages) in the Serbian lands under the Turkish rule. For more, see T. KwokA, Dzieje słownictwa z zakresu stosunków społecznych w Serbii i Czarnogórze, vol. I, Ród i społeczeństwo, Kraków 2012, p. 70.

${ }^{25}$ Atanasije Rašković was highly respected by Arsenije IV because he was married to Anđelija, the patriarch's sister. Cf. I. RuvaraC, Raški episkopi i mitropoliti, G.SKA 62, 1901, p. 35-37; S. GAVRILOvić, Raškovići - starovlaški knezovi i ćesarski oficiri, S.SANU 130, 2004, p. 43, 46.

${ }^{26}$ Podaci o Srbiji u protokolima Dvorskog ratnog saveta u Beču (1717-1740), ed. M. Mitrović, Beo$\operatorname{grad} 1988$ [= S.OIN, 6], p. 312.

${ }^{27}$ J. LANGer, Nord-Albaniens..., p. 276. 
In his "Memorandum", Arsenije IV also raised the issues of schooling and the Rascians' education, in the broad sense of that term. He demanded that it be

allowed to retain public schools and universities, where different sciences will be taught, such as philosophy, theology, law, etc. Out of consideration for the language of the Serbs, they shall be allowed, and others shall be, too, to print books in their respective languages (art. 5) ${ }^{28}$

Therefore, it appears that education mattered for Arsenije IV. It is uncertain what it was that prompted him to raise this issue in his "Memorandum". Maybe his ambition was to establish the Serbian system of education, from elementary schools to universities, or maybe he wanted to found the educated elites of the Serbian nation. There are much more questions surrounding this issue. However, the historical studies concerned with the fortunes of the Serbian community in the first half of the $18^{\text {th }}$ century clearly suggest that education was the aspect which Arsenije IV neglected most $^{29}$.

To sum up the above observations, it needs to be noted that some of the "Memorandum" ideas, such as the establishment of the Supreme Royal Tribunal or the Serbian chamber in Vienna, were not abandoned by the patriarch. Their traces are visible in the extant documents (especially in the 4 May 1741 document) of the Vienna meetings of the delegates representing the Church and the nation. The members of this Serbian committee even went one step further than Arsenije IV had, since they wanted the Supreme Royal Tribunal, operating in the Habsburg Monarchy, to apply the law "of their ancient tsars and kings" ${ }^{30}$, i.e. the legislation of the medieval Serbian state (sic!). Thus, it should come as no surprise that the project was not received favorably by either the monarch or the Austrian administration.

As for Arsenije IV, with the demands he presented to the Habsburg authorities, he confirmed that the notion of the millet, which was characteristic of the Ottoman reality, still typified the mentality of an $18^{\text {th }}$-century leader of the Serbs ${ }^{31}$. Arsenije IV Jovanović Šakabenta passed himself not necessarily as the patriarch of the Serbian Orthodox Church, but as a secular and political leader of the Rascians,

${ }^{28}$ S. GAVRILOVIĆ, Srpski nacionalni..., p. 43.

${ }^{29}$ R. Grujić, Srpske škole (od 1718-1739 g.), Beograd 1908, p. 121-184. N. GavriLović, Školstvo kod Srba i Habsburškoj Monarhiji, [in:] Istorija srpskog naroda. Srbi u XVIII veku, vol. IV.2, Beograd 1994, p. 350-362.

${ }^{30}$ The sessions of the deputation took place in Vienna in May 1741 and were presided over by Arsenije IV. The meeting was called in order to regulate the legal issues pertaining to the residence of the Rascians in the Habsburg Monarchy toward the beginning of Mary Theresa's (1717-1780) reign. The issue of the Serbian chamber in Vienna was no. 5 on the agenda while the Supreme Royal Tribunal was no. 15. See D. Ruvarac, Narodni sabor od 1744. Prilog za istoriju srpskih sabora, SSio 13,1903 , p. $526-530$.

${ }^{31}$ Cf. A. Naumow, Berło innowiercy, [in:] Obraz kapłana, wodza, króla w kulturach słowiańskich, ed. T. DąBek-Wirgowa, A.Z. Makowiecki, Warszawa 1998, p. 15-21; D. GiL, Serbscy etnarchowie..., p. 133-135. 
who was, first and foremost, concerned with their earthly business rather than with their spiritual needs. Additionally, he turned out to be an ambitious politician, who used an opportunity (i.e. the Austrian-Turkish war) to present the Serbian demands to the Austrian rulers. However, it is worth noting here that at the end of 1737 Arsenije IV was not yet too familiar with the convoluted political reality of the Habsburg state, hence the occasional inaccuracies in the "Memorandum". Additionally, it needs to be categorically stated that, although the political program of the patriarch was an interesting concept, it was not possible to implement it in full. Charles VI would never have allowed the constitution, at the periphery of his state, of an autonomous political entity which could threaten the integrity of his monarchy in the future ${ }^{32}$.

Military issues were also of interest to the patriarch, who made attempts toward the formation of a Serbian military unit already during his stay in Vienna. This idea was essentially excerpted from the "Memorandum" and concerned the formation of a regiment composed of the Serbs (art. 9). It needs to be noted that although his political plans did not win too many proponents at the Habsburg court, the Hofkriegsrat, on 4 May 1738, gave its approval to the formation of a unit composed of 2,000 Rascians ${ }^{33}$. However, against Arsenije IV's wishes, placed in command of the unit was not a Rascian but Col. Robert Joseph Graf de la Cerda de Villalonga $(?-1750)^{34}$, who was appointed by the Austrian military. The project of assembling a Serbian regiment fell through. This was mostly caused by Col. de la Cerda himself, since he had no organizational or leadership qualities whatsoever. He could not win over the Serbs, who showed deep distrust in him as a foreign officer, and on top of that he squandered the 1,800 forints which Arsenije IV had given him specifically for that purpose $\mathrm{e}^{35}$.

\footnotetext{
${ }^{32}$ It is also worth noting that to date no written mention has been found that would prove that the "Memorandum" was analyzed by any of the central chambers in Vienna. To be sure, this cannot be construed as evidence that the document did not reach Vienna and was not discussed there. However, it may imply that the Austrians did not give as much weight to this document as claimed in modern Serbian historiography.

Also, it is not clear why a document addressed to emperor Charles VI was stored in the Hungarian State Archive in Budapest [Magyar Nemzeti Levéltár Budapest, Ungarn und Siebenbürgen, sig. A-108 - after S. GAVRILović, Srpski nacionalni..., p. 40]. The extant sources detailing the relations between Arsenije IV and the Austrian political class are only on file in Belgrade, Karlovci, and Vienna. The "Memorandum" is the only document of its kind stored in the Hungarian Archive. It is very unlikely that the document was sent via the Hungarian administrative channels, which could have explained its presence in the Archive's collection: it is a well-known fact that the Serbs did not hold the Hungarians in particularly high regard and they would not have asked them to act as intermediaries in such vital negotiations with Charles VI. This issue is still open to debate and needs further research.

${ }^{33}$ Kriegsarhiv Wien, Protocol Expeditorum, Bd. 232, fol. 1245.

${ }^{34}$ J. LANGER, Nord-Albaniens..., p. 250-251.

${ }^{35}$ Cf. Biblioteka Srpske Patrijaršije u Beogradu (cetera: BSPB), sig. R 186; J. Langer, Nord-Albaniens..., p. 272.
} 
The patriarch left Vienna and returned to Belgrade on 7 June 1738. The notes he kept suggest that straight away he made a military-oriented reconnaissance of the Militärkommandatur des Königreichs Serbien. He was hoping that in mid1738 the Habsburg troops would quickly recapture the Vidin and Niš fortresses, which they had lost the previous year ${ }^{36}$.

Bearing this in mind, Arsenije IV decided to get personally involved in forming a Serbian regiment, which was supposed to come to the aid of the Austrian forces on the Balkan front. That way, he intended to show how willing the Serbian nation was to help Charles VI's troops. The events surrounding the implementation of this plan may be partly reconstructed on the basis of the patriarch's notes and his defter ${ }^{37}$. These sources also reveal that already on 21 June 1738 Arsenije IV met with ten most influential leaders of Serbian clans. These included Hadži Jovan Leskovčanin, Radosav Prokupac, Stefan Brvenički, Boško Tetovski, Stanoje Zvečanski, Milutin Dugopoljski, Ilija Saktijanović, Stanko Radojkov, Nikola Vukasović and Miljko Jakovljević. The chief goal of this meeting was to persuade the clan leaders to draft a sufficient number of recruits who would form a new Serbian regiment. Arsenije IV allocated relevant resources for that purpose. On 22 June, he recorded that he had given

15 ducats to Stanko Radojkov so he would go to Srem and get men; 15 ducats to Cpt. Hadži Jovan, to draft [lit. bribe] people to the regiment ${ }^{38}$.

Gathering men for Serbian units (Ser. čet), with a view to forming a regiment, was progressing rather well. In July 1738, Arsenije IV wrote that

in the village of Palez, 200 men gathered, under the command of Cpt. Vidovski, Cpt. Radasov, and Stanko. 300 men arrived in Palanka, under the command of Cpt. Hadži Jovan. On 24 July, I gave him 30 florins. $^{39}$

It is believed that the basic task that Arsenije IV gave these units was to gather intelligence on the deployment of the Turkish forces on the Rascian fatherlands. He anticipated that after the unblocking of Orșova the Habsburg troops would head for Vidin and Niš, and at that point they would need up-to-date intelligence on the deployment of the Ottoman forces. However, these expectations were again not borne out since after claiming Orșova the Austrian troops retreated

\footnotetext{
${ }^{36}$ This did not happen because the Austrian forces went east to claim Orşova. See V. AksAN, Ottoman Wars (1700-1870). An Empire Besieged, New York 2007, p. 112-113.

${ }^{37}$ This word likely comes from Turkish, where it means 'log', 'notebook', 'register,' 'list'. See T. KwoKA, Dzieje słownictwa $z$ zakresu stosunków społecznych w Serbii i Czarnogórze, vol. II, Państwo i administracja, Kraków 2013, p. 166.

${ }^{38}$ BSPB, sig. R 186.

${ }^{39}$ Ibidem.
} 
to the territory of the Military Command of the Kingdom of Serbia. Then, in midAugust 1738, the Austrian military leaders decided to end military operations for the year ${ }^{40}$.

Having concluded that his efforts toward establishing a new regiment were not effective, Arsenije IV decided that, starting in the second half of 1738, full authority over Serbian military issues would be given to his brother-in-law, knez Atanasije Rašković, whom the Serbs held in very high regard ${ }^{41}$.

In September and October 1738, the patriarch's relative managed to unite individual Rascian units, thus creating a military unit which the Habsburg sources refer to as "the Albanians and the Kelmendi" ${ }^{2}$. Unfortunately, a rather partial character of the sources means it is impossible to give the exact number of soldiers in this unit. In a note made for the Hofkriegsrat, Col. Robert de la Cerda claimed that the unit was very small and consisted of no more than 150 men $^{43}$. However, Arsenije IV, in a letter to Charles VI dated 6 September 1738, wrote about "a huge Serbian unit" which numbered more than 800 men. Col. de la Cerda's estimations may be discounted, since he was not too familiar with the Rascian units. Additionally, given his previous failure to form a regiment, he openly disliked the Serbs, which possibly translated into the negative narrative he produced for the sake of the Viennese military circles. On the other hand, the numbers quoted by Arsenije IV did not necessarily reflect the actual strength of the Serbian unit either, because the patriarch, from the very beginning of his contacts with Vienna, painted the Rascians in the best possible light. He tried to convince the contemporary Austrian political class that the Serbs were their closest allies in the conflict with the Ottoman Empire ${ }^{44}$. However, it needs to noted that the numerical strength of Rašković's unit must have been considerable because toward the end of 1738 the Austrian military command of Belgrade decided to divide it, feeling uneasy about too heavy a concentration of armed Serbs in the Sava and Danube basin. Most of the soldiers were incorporated into the border militia units under the command of Vuk Isakovic ${ }^{45}$. They were to defend the monarchy's southern perimeter against any Turkish hostilities.

Toward the end of 1739, that is already after the Austrian-Turkish war had concluded, sources quote a verified number of 355 Serbian soldiers who were staying in the territories of the Habsburg monarchy. According to the records compiled by Aleksandar Rašković, Atanasije’s son, the Rascians were grouped in eight units. It needs to be noted here that these units were internally uniform, i.e. they were either cavalry or infantry, but the dominant role in this group was played

\footnotetext{
${ }^{40}$ V. Aksan, Ottoman Wars..., p. 113-114.

${ }^{41}$ ASANUK, MPB, sig. 1741/74.

${ }^{42}$ Podaci o Srbiji u protokolima..., p. 325.

${ }^{43}$ J. LANGer, Nord-Albaniens..., p. 251-252.

${ }^{44}$ Stari srpski zapisi i natpisi, vol. II, ed. L. Stojanović, Beograd 1983, no. 2784.

${ }^{45}$ Podaci o Srbiji u protokolima..., p. 325.
} 
by Atanasije Rašković. The documents stored in the Library of the Serbian Patriarchate clearly suggest that all the captains, except Đoka and Deda ${ }^{46}$, answered to Rašković ${ }^{47}$, who, in recognition of his service to the Austrian state, was promoted to the rank of colonel on 15 March 1739.

When the Hofkriegsrat decided to expand the Military Frontier to include the territories between Rača and Zemun - for which the patriarch had lobbied - the 355 soldiers and their families were not only given the status of free peasants-soldiers, but also received plots of land around Sremska Mitrovica. These steps taken by the Habsburg authorities were, on the one hand, supposed to secure the monarchy's southern borders, and to push the Serbs toward sedentism, on the other, since the Austrian political leaders believed that if the Rascians were to continue living seminomadic life, they might be a serious threat to peace in the southern territories of the lands of the Crown of Saint Stephen ${ }^{48}$.

In short, Arsenije IV did not achieve much success with military planning either. On the contrary, his predictions were wrong both with regard to the movement of the Habsburg army and the chances of forming a "great Serbian regiment". His only right decision was to delegate the job of forming the Serbian regiment to knez Atanasije Rašković, his brother-in-law.

Toward the beginning of 1738, Arsenije IV was very optimistic about the future of the Serbian Church, detecting a huge opportunity to consolidate the Autocephalic Serbian Orthodox Church, which, following wars and subsequent peace treaties, was divided into the Peć Patriarchate and the Metropolitanate of Belgrade and Karlovci. Of course, he was aware of various threats, especially from the Ottomans. However, he thought that the war's final outcome would neutralize the Turkish danger ${ }^{49}$.

Mindful of the issue of uniting the Church, the patriarch believed that all Serbs living in the Habsburg monarchy must act as one, and that particular eparchs should forget about any mutual animosities. This sentiment is echoed in his letter to Vasilije Dimitrijević, the eparch of Buda, dated 15 May 1738, in which he pointed to the necessity of holding a popular assembly $(\text { sabor })^{50}$ in Belgrade on the day of Peter and Paul apostles, i.e. on 29 June $^{51}$. Arsenije believed that such an assembly of Church hierarchs and representatives of the Serbian people would

\footnotetext{
${ }^{46}$ Đoka and Deda did not answer directly to Rašković because they were Catholics. Vide: S. GAVRILOvić, O naseljavanju srpske milicije i Klimenata u Sremu 1732-1742, IČ 9/10, 1960, p. 254.

${ }^{47}$ BSPB, sig. R 186.

${ }^{48}$ Cf. M. Kostić, Ustanak Srba i Arbanasa u Staroj Srbiji protiv Turaka 1737-1739 i seoba u Ugarsku, GSND 7-8, 1930, p. 226-233; S. GAVRILOvić, O naseljavanju srpske..., p. 249-258.

${ }^{49}$ BSPB, sig. R 186.

${ }^{50}$ Under the Habsburg Monarchy, a sabor was an assembly of Orthodox Church hierarchy, lower clergy, lay representatives of the Serbian nation, and representatives of state authorities. For more, see I. TočAnaC, Srpski narodno-crkveni sabori (1718-1735), Beograd 2008, passim.

${ }^{51}$ Muzej Srpske Pravoslavne Crkve u Beogradu, Ostavina Radoslava Grujića, sig. A/927; A/957.
} 
demonstrate the unity of the whole Orthodox community to the Austrian leaders staying in Belgrade at that time, such as duke Francis of Lorraine or Fieldmarshal Joseph Lothar von Königsegg-Rothenfels (1673-1751) ${ }^{52}$. Arsenije IV thought that the chief goal of the assembly should be to discuss issues pertaining to the future of the Serbian Orthodox Church. He was particularly intent on laying out a project of a new administrative division of the Serbian Orthodox Church. It appears that he wanted to sound out the reactions of the hierarchs and Austrian representatives to his plan. However, he never found out about any of these since the assembly was not held. The hierarchs of the Metropolitanate of Belgrade and Karlovci did not come to Belgrade and only two of them excused their absences. One was Nikola Dimitrijević, the eparch of Temešvar, who could not leave the city due to the black death epidemic, which saw the whole Banat region quarantined, and nobody was allowed to move outside the area without special clearance ${ }^{53}$. The other was Danilo Ljubotina, the eparch of Gornji Karlovac ${ }^{54}$ : he was already a very sick man and was not able to travel the distance of a few hundred miles between Plaški and Belgrade ${ }^{55}$. It is not clear why the other eparchs failed to turn up. The greatest disappointment for Arsenije IV was the absence Visarion Pavlović, the eparch of Bačka, whom he considered one of his closest allies. When the patriarch was setting up the meeting with duke Francis and Lothar von Königsegg-Rothenfels, Pavlović was in Vienna, conspiring against Arsenije IV. He demanded that the assets he possessed as the metropolitan of Belgrade and Karlovci be reduced by a sizeable property in the village of Dalj.

The behavior of the Church hierarchs was undoubtedly a big surprise to Arsenije IV: never before had he experienced such affront from the eparchs. In a letter to Vasilije Dimitrijević, he did not hide his disappointment, writing that he sensed a huge discord among all of us, which will eventually be our undoing ${ }^{56}$.

This was Arsenije IV's first but not last unsuccessful attempt to assemble the eparchs in order to discuss issues vital for the whole nation. In a letter to Isaija Antonović, the eparch of Arad, dated 14 August 1740, Arsenije IV expressed, in rather strong terms, his disapproval of how the eparchs were acting (for three years now I have been requesting that all of us meet, all in vain $)^{57}$. He did not understand the actions of the eparchs of the Metropolitanate of Belgrade and Karlovci, and for that reason he suggested that they follow the example of the Serbian

\footnotetext{
${ }^{52}$ Fieldmarshal Joseph Lothar von Königsegg-Rothenfels (1673-1751) served as the president of the Imperial War Council (Hofkriegsratspräsident) between 1736 and 1738. See O. Regele, Der österreichische Hofkriegsrat (1556-1848), Wien 1949, p. 76.

${ }^{53}$ R. Grujić, Borbe s Turcima u Banatu 1738 i 1739, GIDNS 3, 1930, p. 106-109.

${ }^{54}$ Danilo Ljubotina died on 29 January 1739. For more, see N. Perović, Danilo Ljubotina, episkop karlovačko-primorski, [in:] Srpski Biografski Rečnik, vol. V, Novi Sad 2011, p. 716-717.

${ }^{55}$ In the 1730s, the seat of the Eparchy of Gornji Karlovac was in the monastery in Plaški (Gorska Hrvatska).

${ }^{56}$ ASANUB, Kulturno-Istorijska Zbirka (cetera: KIZ), sig. 1948.

${ }^{57}$ Univerzitetska Biblioteka u Beogradu, Arhivska Zbirka Odeljenja Retkosti, sig. 2487.
} 
Church hierarchs from the Ottoman Empire, whom he believed to be more concerned about the Serbian people. In the aforementioned letter, he wrote that

it would be desirable if the Brothers [eparchs] could follow in the footsteps of those Serbian hierarchs who still live under the Muslim oppression but have a much greater understanding of unity than you do here [in the Habsburg monarchy], living in a free country and enjoying privileges $^{58}$.

Fractious relations with parts of the episcopate, a poor financial condition of the Metropolitanate of Belgrade and Karlovci, and no prospects of any global improvements meant that Arsenije IV found himself in a critical situation. It was so serious that the patriarch even considered resigning from office. In a letter to Vasilije Dimitrijević, whom he regarded as one of few close friends at that time, he wrote that

if the Brothers, the venerable clergy, and the great Serbian people do not want me to be their spiritual leader, then I shall not object. However, I will serve the Emperor until the end of my life. I will also ask him to give me some dwelling, where I will be living quietly, being a burden to nobody. I can see, nevertheless, that I am closer to death than to living. ${ }^{59}$

Arsenije IV's plan to join the two parts of the Serbian Orthodox Church already in 1738 provokes a number of questions as to whether it was possible to implement. Also, doubts arise concerning the patriarch's familiarity with international and intra-Church affairs: Arsenije IV could not be certain if the Austrian authorities, after the war with Turkey, would allow the existence of an Orthodox Church with the status of a patriarchate, which would have had to apply to the consolidated Serbian Church $^{60}$. His attempts to demonstrate to the Habsburgs the oneness of the Orthodox community were also unsuccessful. All they did was prove that Arsenije IV did not enjoy unassailable authority among the Serbian higher clergy from the Habsburg monarchy. Already during the first months of his functioning within the structures of the Metropolitanate of Belgrade and Karlovci, the patriarch realized that his position was not as strong as in the Peć Patriarchate. It was also a hint that in his future political plans he should be mindful of the ambitions of individual eparchs to a much greater extent than he was in previous years. Otherwise, he would be looking at another defeat, as in the case of the Belgrade sabor of June 1738, which he mishandled.

Translated by Maciej Grabski

\footnotetext{
${ }^{58}$ Ibidem.

${ }^{59}$ ASANUB, KIZ, sig. 1950.

${ }^{60}$ These concerns were not unfounded since already under Leopold I's privileges for the Serbian community (1690-1695) the Habsburgs only admitted a possibility of establishing an archbishopric in their ultra-Catholic state. Cf. Srpske privilegije..., p. 19-45; D. DAvidov, Srpske privilegije..., p. 89-102.
} 


\section{Bibliography}

\section{Primary Sources}

Arhiv Srpske Akadamije Nauka i Umetnosti u Beogradu, Kulturno-Istorijska Zbirka.

Arhiv Srpske Akadamije Nauka i Umetnosti u Sremskim Karlovcima, Metropoliljsko-Patrijaršijski fond $\mathrm{B}$.

Barinyay I., Palatini regni Hungariae, Tyrnaviae 1753.

Biblioteka Srpske Patrijaršije u Beogradu.

Honváth M., Statistica regni Hungariae et partiam eidem adnexarum, Posonii 1802.

Kriegsarhiv Wien, Protocol Expeditorum.

Muzej Srpske Pravoslavne Crkve u Beogradu, Ostavina Radoslava Grujića.

Podaci o Srbiji u protokolima Dvorskog ratnog saveta u Beču (1717-1740), ed. M. Mitrović, Beograd 1988 [= Spomenik. Odeljenje Istorijskih Nauka, 6].

Srpske privilegije od 1690 do 1792, ed. M. Kostić, J. Radonić, Beograd 1950.

Stari srpski zapisi i natpisi, vol. II, ed. L. STOJAnović, Beograd 1983.

Univerzitetska Biblioteka u Beogradu, Arhivska Zbirka Odeljenja Retkosti.

Znamenita dokumenta za istoriju srpskog naroda 1538-1918, ed. V. Gavrilović, D. MikavicA, G. VASIN, Novi Sad 2007.

\section{Secondary Literature}

Aksan V., Ottoman Wars (1700-1870). An Empire Besieged, New York 2007.

Andonovski H., Makedonija i Vojvodina. O nikim međusobnim vezama u prošlosti, "Zbornik Matice Srpske za Društvene Nauke" 23, 1959, p. 5-25.

Anisimov E., Rossija biez Pëtra, Sankt-Peterburg 1994.

Avtobiografija Partenija Pavlovića episkopa posvećenja, “Srpski Sion” 15, 1905, p. 14-15, 17-19, 396-399, 430-432, 493-495, 526-528, 553-556.

BaIov A., Russkaja armija v carstvovanie imperatricy Anny Ioannovny. Vojna Rossii s Turciej v 17361735 gg., vol. I, Pervye tri goda vojny, Sankt-Peterburg 1906.

ČAKIĆ S., Velika seoba Srba 1689/90 i patrijarh Arsenije III Crnojević, Novi Sad 1994.

DAvidov D., Srpske privilegije carskog doma habzburškog, Novi Sad 1994.

Gavrilović N., O naseljavanju srpske milicije i Klimenata u Sremu 1732-1742, "Istorijski Časopis" 9/10, 1960, p. 249-258.

Gavrilović N., Raškovići - starovlaški knezovi i ćesarski oficiri, "Spomenik SANU” 130, 2004, p. 7-66.

GavrILović N., Školstvo kod Srba i Habsburškoj Monarhiji, [in:] Istorija srpskog naroda. Srbi u XVIII veku, vol. IV.2, Beograd 1994, p. 350-362.

GaVrilović N., Srem od kraja XVII. do sredine XVIII. Veka, Novi Sad 1979.

GAVRILović N., Srpski nacionalni program patrijarha Arsenija IV Jovanovića Šakabente iz 1736-37. godine., "Zbornik Matice Srpske za Istoriju” 44, 1991, p. 39-48. 
Gil D., Prawosławie. Historia. Naród. Miejsce kultury duchowej w serbskiej tradycji i współczesności, Kraków 2005.

GIL D., Serbscy etnarchowie jako kodyfikatorzy tradycji kulturowej, [in:] U spomen na Borivoja Marinkovića. Zbornik Filozofskog Fakulteta, ed. N. Grdinić, S. Tomin, N. Varnica, Novi Sad 2014, p. 132-139.

Goffman D., The Ottoman Empire and Early Modern Europe, Cambridge 2004.

Grujić R., Borbe s Turcima u Banatu 1738 i 1739, "Glasnik Istoriskog Društva u Novom Sadu” 3, 1930, p. 106-109.

GRUIĆ R., Kako se postupalo sa srpskim molbama na dvoru ćesara avstrijskog poslednje godine života patrijarha Arsenija III Čarnojevića, Novi Sad 1906.

GrujIĆ R., Pećki patrijarsi i karlovački mitropoliti u 18. veku, Sremske Karlovci 1931.

Grujić R., Srpske škole (od 1718-1739 g.), Beograd 1908.

GrujIĆ R., Velika Seoba patrijarha Arsenija III Crnojevića iz južne Srbije u Vojevodinu pre dvestapedeset godina, Skoplje 1940.

Inalcik H., Quataert D., Dzieje gospodarcze i społeczne Imperium Osmańskiego, Kraków 2008.

Jezernik B., Dzika Europa. Bałkany w oczach zachodnich podróżników, trans. P. Oczko, Kraków 2007.

Judah T., The Serbs. History, Myth and the Destruction of Yugoslavia, London 1997.

Kaplan B., Divided by Faith. Religious Conflict and the Practice of Toleration in Early Modern Europe, Cambridge-London 2007.

Kočubinskij A., Graf Andrej Ivanovič Osterman i razdel Turcii. Iz istorii vostočnogo voprosa. Vojna pjati let (1735-1739), Odessa 1899.

Kostić M., Ustanak Srba i Arbanasa u Staroj Srbiji protiv Turaka 1737-1739 i seoba u Ugarsku, "Glasnik Skopskog Naučnog Društva” 7/8, 1930, p. 214-236.

Kręzel P., Analiza językoznawcza przywilejów Leopolda I z 1690 r., "Die Welt der Slaven. Sammelbände" 46, 2012, p. 143-147.

Kwoka T., Dzieje słownictwa z zakresu stosunków społecznych w Serbii i Czarnogórze, vol. I, Ród i społeczeństwo, Kraków 2012.

Kwoka T., Dzieje słownictwa z zakresu stosunków społecznych w Serbii i Czarnogórze, vol. II, Państwo i administracja, Kraków 2013.

LANGer J., Nord-Albaniens und der Herzegowina Unterwerfungs-Anerbieten an Oesterreich 1737-1739, Wien 1880.

Lis-Wielgosz I., O trwałości znaczeń. Siedemnastowieczna literatura serbska $w$ służbie tradycji, Poznań 2013.

Lis-Wielgosz I., Władza i rodowód. O wizerunku władcy w staroserbskiej literaturze, "Poznańskie Studia Slawistyczne" 5, 2013, p. 173-184.

Lis-Wielgosz I., Władza turecka i strategie jej opisu w piśmiennictwie staroserbskim (na przykładzie krótkich form literackich - zapisów), "Balcanica Posnaniensia. Acta et studia” 21, 2014, p. 25-49.

Malcolm N., Kosovo. A Short History, London 1998.

MiкоŁajczaк M., Mehmed pasza Sokollu - problem przynależności etnicznej, państwowej i kulturowej, "Balcanica Posnaniensia. Acta et studia" 16, 2009, p. 59-69.

Mirković M., Pravni položaj i karakter srpske crkve pod turskom vlašću (1459-1766), Beograd 1965. 
Morawski W., Szawıowska S., Wojny rosyjsko-tureckie od XVII do XX wieku, Warszawa 2006.

Naumow A., Berło innowiercy, [in:] Obraz kapłana, wodza, króla w kulturach słowiańskich, ed. T. DĄBeK-Wirgowa, A.Z. Makowiecki, Warszawa 1998, p. 15-21.

Perović N., Danilo Ljubotina, episkop karlovačko-primorski, [in:] Srpski Biografski Rečnik, vol. V, Novi Sad 2011, p. 716-717.

Regele O., Der österreichische Hofkriegsrat (1556-1848), Wien 1949.

Roider K., Futile Peacemaking: Austria and the Congress of Niemirov, "Austrian History Yearbook" 12/13, 1976/1977, p. 95-116.

Roider K., The Reluctant Ally. Austria's Policy in the Austro-Turkish War, 1737-1739, Baton Rouge 1972.

Ruvarac D., Narodni sabor od 1744. Prilog za istoriju srpskih sabora, “Srpski Sion” 13, 1903, p. 526-530.

RUVARAC I., Raški episkopi i mitropoliti, “Glas SKA” 62, 1901, p. 35-37.

SHAw S., Historia Imperium Osmańskiego i Republiki Tureckiej (1280-1808), vol. I, trans. B. ŚwIETLIK, Warszawa 2012.

Shaw S., The Ottoman View of the Balkans, [in:] The Balkans in Transition. Essays on the Development of Balkan Life and Politics since the Eighteenth Century, ed. B. Jelavich, C. Jelavich, London 1963, p. 56-80.

Simeonović-Čokić S., Srpske privilegije, [in:] Vojvodina II. Od Velike Seobe (1690) do Temišvarskog Sabora (1790), Novi Sad 1940, p. 48-85.

Solov'IEv S., Istorija Rossii s drevnejšych vremen (1725-1740), Moskva 1963.

StoJAnČEvić V., Presek kroz istoriju srpskih seoba od XIV do početka XVIII veka, "Zbornik Matice Srpske za Istoriju" 41, 1990, p. 7-24.

Šrirokorad A., Turcija. Pjat' vekov protivostojanija, Moskva 2009.

Šul'man E., O pozicii Rossii v konflikte s Turciej v 1735-1736 gg., “Балканский Исторический Сборник" / "Balkanskij Istoričeskij Sbornik" 3, 1973, p. 5-61.

TočANAC I., Srpski narodno-crkveni sabori (1718-1735), Beograd 2008.

\begin{abstract}
Arsenije IV Jovanović Šakabenta (1698-1748) was one of the last leaders of the Peć Patriarchate. The period of his service coincided with the so-called Second Great Migration of the Serbs, i.e. the migration of portions of the Serbian society from Kosovo and Metohija to the southern territories of the Habsburg monarchy. This event majorly determined the actions of the patriarch at the end of the 1730s. The article outlines the political ambitions of Arsenije IV, which he tried to realize around that time. Particular focus is given to his vision of the Serbian community under the Habsburgs and to his efforts to retain the privileges which the Serbs had been granted by emperors Leopold I, Joseph I, and Charles VI. Additionally, the analysis covers the internal dynamics of the Serbian Orthodox Church in the territories of the Habsburg monarchy. The paper also touches upon the military issues and discusses the role of Serbian soldiers in the political plans of Arsenije IV Jovanović Šakabenta.
\end{abstract}


Keywords: Arsenije IV Jovanović Šakabenta, Second Great Migration of the Serbs, Serbian Orthodox Church, Austrian-Turkish War of 1737-1739, Serbian millet.

Piotr Kręzel

University of Łódź

Faculty of Philology

Department of Slavic Philology

ul. Pomorska 171/173

90-236 Łódź, Poland

piotr.krezel@uni.lodz.pl 